\title{
God's Mercy is Broader than This: Theological Sensibilities and Interreligious Theological Education
}

\author{
Timur Yuskaev
}

\begin{abstract}
Why and how does interreligious theological education matter? In this chapter I reflect on such questions through in-the-field experiences of Muslim chaplains trained at Hartford Seminary. In moments of crisis-situations that viscerally encapsulate multitudes of embodied histories and hierarchies of power-chaplains rely on seminary courses that interweave theological, comparative and pastoral threads. The intersectional quality of such coursework is impactful because it is formational: it enables seminary students to hone a more nuanced, deeper sense of the pluralistic spaces they inhabit. Employing William E. Connolly's theory of pluralism, I argue that interreligious theological education matters when it adds depth to the experience and politics of pluralism.
\end{abstract}

Each word (each sign) of the text exceeds its boundaries. MIKHAIL BAKHTIN ${ }^{1}$

A preliminary commitment to deep, multidimensional pluralism is amplified by the experience of belonging to time.

WILLIAM E. CONNOLLY2

1 Mikhail Bakhtin, Toward a Methodology for the Human Sciences: Speech Genres \& Other Late Essays, trans. Vern W. McGee (Austin, TX: University of Texas Press, 1986), 161.

2 William E. Connolly, Pluralism (Durham, NC: Duke University Press, 2005), 169.

(C) TIMUR YUSKAEV, $2020 \mid$ DOI:10.1163/9789004420045_010

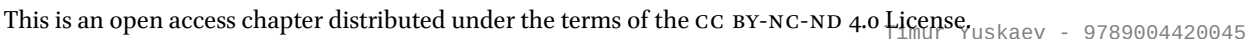


"She is wearing a scarf!" gasped a volunteer Muslim Sunday school teacher at a detention center for young women. The teacher and de-facto Muslim chaplain had been visiting the facility for months. Many of its inmates, twelve- to eighteen-year-old girls, were Muslim. None of them wore hijab: it was against rules that had been set in place because some girls had committed suicide by hanging themselves with their headscarves. Whenever a newcomer wearing a scarf arrived at the institution the staff made sure to enforce the regulation quickly and efficiently. It had always worked. Yet this diminutive fourteen-yearold girl, who looked even younger, was still wearing her scarf many hours, perhaps a full day, after being admitted. "How did they let you do this?" the teacher asked. "Well, you know," she responded, "if I take it off, I'm going to hell."

Many factors influenced what happened next. At the time, the teacher was also a student in Hartford Seminary's Islamic Chaplaincy program, so she approached the situation as a chaplain. "I remember thinking," she told me in an interview, "that I have to address this and have to do this carefully." She knew that she would likely get a chance to speak with the girl in hijab only once. Most inmates would stay at the facility briefly before being transferred someplace else. The audience for the chaplain's monthly lessons rotated constantly, and the girls' presence and attention was fleeting. Within minutes the chaplain assessed the situation and decided to hold a class, or rather a conversation, with "three girls" - the institution's entire population of incarcerated Muslims on that particular day. "Let's talk about a concept," she suggested to them, "What do you think about God? What is your relationship with Him?" The discussion "started with mercy, and it [was] not as black and white [as some might think]."3

Why — and more importantly how — does interreligious theological education matter? What and how do we teach? In fact, what is interreligious and theological about the education our students go through? This chapter reflects on these questions through stories of graduates of one interreligious theological school, Hartford Seminary, where I have been teaching since 2010. I know Hartford Seminary as an extraordinarily welcoming place for religious minority students, particularly Muslims. For example, in 2016, when I was writing this essay, 39 percent of our students were Muslim. Most of our Muslim students are in the Islamic Chaplaincy program, which I happen to direct. Founded in 1999 by Ingrid Mattson, the program is a MDiv equivalent 72-credit hour combination of the MA in Religious Studies and the Graduate Certificate in Islamic Chaplaincy. While preparing to write this essay, I did what I always do: I taught courses ranging from "Muslims in American Religious History" to

3 Anonymous, interview with author, May 16, 2016. 
"Religion and Public Life" and a skills-aimed "Muslim Public Speaking," and a theology-designated course in "Muslim Political Theology in $20^{\text {th }}$ and $21^{\text {st }}$ Centuries" - and I conversed with current students and graduates. Keeping this project in mind, I looked to those conversations for stories and insights that might go into this chapter. In seven cases I scheduled follow-up interviews, and two of these interviews anchor this essay as its case studies.

In this case of the interview that included the story from within the walls of a detention center, described above, my conversation partner and interviewee will remain anonymous. At the time, she was my student, and now she is a chaplain. We agree that confidentiality is imperative in our work-it affects human beings and if we are not careful, such effects might be negative. The second case study is based on a published article, and my interlocutor in this case was Bilal Ansari, a 2011 graduate of the Islamic Chaplaincy program. On September 13, 2015, Ansari posted an online article, "Thug Life TheodicyA Mustard Seed of Faith: Reflections on the 2oth Anniversary of Tupac Shakur's Song 'So Many Tears."'4 Ansari and I spoke about that piece in May 2016. At the time, he served as the Dean of Students at Zaytuna College, a Muslim liberal arts college in Berkeley, CA. "Thug Life Theodicy" was one of many examples of the ways in which Ansari serves as both a chaplain and a public intellectual with a voice.

In conversations with my anonymous interlocutor about an incarcerated hijabi resister and with Ansari about his "Thug Life Theodicy," I asked them both to talk about what prepared them to respond to each situation the way they did. I discovered that in both cases, as different as they were, each acted on their professional instincts: the teacher conducted her class as a chaplain, and Ansari reflected on Shakur's "So Many Tears" as a chaplain as well. Therefore, I ended up prompting them to reflect on the instincts behind their choices of words and actions. In the back of my mind and expressed through a variety of questions was a search for theology in their actions. Practically speaking, I wanted to trace glimpses of their Hartford Seminary training in their lived theology.

Of course, my interlocutors' theology is broader-and its roots run deeperthan a cursory review of their formal theological curriculum might suggest. Both come from Muslim families: my anonymous interlocutor is female, in her late twenties or early thirties, Arab American, Shi'i, and not yet a parent. Ansari is male, in his early forties, African American, Sunni, and a father of four children. Before and after their careers at Hartford Seminary, both had

4 Bilal Ansari, "Thug Life Theodicy-A Mustard Seed of Faith: Reflections on the 2oth Anniversary of Tupac Shakur's Song 'So Many Tears,"' accessed June 23, 2017, https://ummahwide .com/thug-life-theodicy-a-mustard-seed-of-faith-5bb62c88dfc2\#.15vjgwcvg. 
multifaceted and extensive professional and educational experiences. My anonymous collaborator had substantial experience as a caseworker at a nonprofit serving low-income families; Ansari had worked as a chaplain at the Federal Correctional Institution for women in Danbury, Connecticut, and served as the Muslim chaplain at Williams College in Massachusetts. Both of these chaplains' work reflect broader trends in North American theological education: Ansari wrote "Thug Life Theodicy" while pursing the Doctor of Ministry degree at the Pacific School of Religion, and both he and his younger colleague took courses at Hartford Seminary with faculty who had also been teaching at other institutions.

The gist of my argument in this paper is found in the opening quotes from Bakhtin and Connolly. In my dialogues with the seminary's Muslim students and graduates, I searched for stories that encapsulate what we (they, I, other faculty, our institution) do. I found that their theology—what went into the word "theology" when they spoke it-exceeded the boundaries of what one would ordinarily understand by that term, particularly as it is framed within academic curricula. In moments where their theological training really mattered, what they relied upon went beyond the formal lessons they had learned in courses designated as "Theology." Undeniably, theology courses were crucial: they provided a degree of fluency in the conceptual vocabulary and discursive grammar of their own and other traditions. But what proved to be vital was that Hartford Seminary had helped them to hone their theological sensibilities in ways that resonated with their pastoral work, in their professional settings. To explain this, I begin with Ansari's "Thug Life Theodicy" and then move to the conclusion of the "going to hell" episode. In part, this structure is chronological, as Ansari was a student at the seminary before his anonymous colleague. Their joint trajectories reflect a slice of the institution's history. Finally, after discussing how interreligious theological education matters, I offer a reflection on why it does. This is where Connolly's notion of deep, multidimensional pluralism comes in. Central in my case studies is a deep, multidimensional, and theology-infused sense of time.

Ansari's timing was impeccable: he published "Thug Life Theodicy" on September 13, 2015, twenty years to the day after the release of Tupac Shakur's "So Many Tears." That song-a "powerful spiritual hymn," as Ansari described it - presaged Shakur's death by exactly one year. ${ }^{5}$ Ansari published his reflection in Umma Wide, an online magazine with 1,300 Twitter followers that

5 Bial Ansari, interview with author, May 18, 2016. 
describes itself as "a digital media startup telling stories that transcend the borders of global Muslim communities." 6 Umma Wide promised its readers that Ansari's piece would be a " 7 min read." (What it did not mention is that seven minutes only allows for a compressed, surface read of the piece.)

"Thug Life Theodicy" is a deep theological reflection delivered in the genre of a cyber sermon. It follows the basic structure of a khutba, the Islamic Friday congregational sermon, consisting of two units (first and second khutbas, as khatibs, Muslim preachers call these units), with a meditative break in between. At the beginning of the first unit there are two scriptural quotes, from the New Testament and the Qur'an, both relating the parable of the mustard seed: "If you had faith even as small as a mustard seed ... nothing would be impossible" (Matt. 17:20), and, "We will set up a just balance on the day of resurrection, no soul shall be dealt with unjustly in the least; and though there be the weight of a grain of mustard seed, [yet] will We bring it" (Qur'an 21:47). Ansari concluded the first khutba with a prayer on his audience's behalf, inviting them to follow in his step:

Whether you live in deserted Detroit or Damascus, wait in prison in Philadelphia or Occupied Palestine, or are bomb survivors in Boston or Baghdad, may God hear the prayers of the archetypal Black man clinging on to a "mustard seed of faith," boldly hoping and longing for a better life to come.

Ansari infused the break between the two units with a long quote form "So Many Tears," in which is Shakur's vital appeal and lamentation is evident:

Is there heaven for a G? Remember me So many homies in the cemetery, shed so many tears

Ahh, I suffered through the years, and shed so many tears Lord, I lost so many peers, and shed so many tears

At the end of Ansari's sermon is a supplication, which I will address later. Preceding it is a lesson (dars):

Tupac Amaru Shakur cries out the struggle and misery of a child in a violent environment without family roots. His lack of education leads him to a business dirty and demonic. He was constantly intoxicated, which, in the urban streets, we call "medicated." In this state of mind, he concluded

6 Ummah Wide, accessed March 20, 2017, https://ummahwide.com. 
it was impossible for him to be anything other than a seed; he longed to be laid to rest where he would find peace in the dirt like so many of his peers. Yet this state did not prevent him from repenting and hoping for God's forgiveness, mercy, and ultimate grace. He lived and died on the meaning of his Arabic last name, Shakur, as he did recognize and appreciate the transcendent capacity of a generous giver of grace who he called upon repeatedly as his God and Lord. Although he shed so many tears and failed to live a righteous life, his hope prevailed for a God who would grant him redemption.

The "we" in this quote identifies Ansari's audience: as a skillful preacher, he signals his connection to them by including himself in the collective "we." That "we" is also an indication of Ansari's sense of timing. As he explained to me in an interview, he wrote the piece "for young college-age hearts and minds who are struggling with finding their place, and [for] African Americans and Muslims - those who are going through hard times here and identify with hiphop as a genre of resistance." By "resistance," Ansari meant Black Lives Matter, a movement that emerged in 2013 with a hashtag, after the murder of Trayvon Martin, an African American teenager, and the subsequent acquittal of his killer. By 2015, spurred by more killings at the hands of law enforcement, of children (Tamir Rice), women (Korryn Gaines), and men (Keith Lamont Scott), Black Lives Matter became a civil rights movement, an Internet-era iteration of James Baldwin's "the fire next time."7 To Ansari, that time had a particular sense: "There is so much pain, so much apathy within African American community.... So I used [the piece] to give hope to everybody who reads it and [is] going through a thing like that."

How does Ansari's cyber sermon reflect his theological education at Hartford Seminary, the Pacific School of Theology, and beyond? To answer this question, we have to start with the "beyond," which comes across in his instinctual and confident use of the word "redemption," the last word in the sermon's lesson/dars: "[Tupac's] hope prevailed for a God who would grant him redemption." Ansari began his studies at Hartford Seminary in 2006 at the age of thirtyfive. Before then, his "theological preparation was of a Smörgåsbord type." He was involved in several Muslim networks, and had listened to and studied with many Muslim authorities, including Zaid Shakir and Hamza Yusuf, co-founders of Zaytuna College. His base, however, was within the community of Warith Deen Mohammed, an African American Sunni Muslim movement that grew out of the Nation of Islam of Elijah Muhammad and Malcolm x.

7 See Black Lives Matter, accessed March 21, 2017, http://blacklivesmatter.com. 
Before Hartford Seminary, Ansari explained, he had been "blessed to listen to the lectures of Imam Mohammed." In W. D. Mohammed's teachings, the word "redemption" was the shibboleth, the password that reveals how God speaks to African Americans through scripture, the Qur'an and the Bible, as well as through history and nature. ${ }^{8}$ Ansari's fluent interweaving of the message of redemption, which he found in the Bible and the Qur'an, comes from the years he spent listening to W. D. Mohammed. Behind this somewhat obvious dynamic, there is a deeper layer: "W. D. Mohammed," Ansari remembered, "was just a modest, humble man who worked and served those he was called to serve." In other words, underpinning and informing W. D. Mohammed's theological articulations was the purpose of serving his community. Ansari recalled that he had sensed this service-oriented nature of his and W. D. Mohammed's theology all along. At Hartford Seminary, he found a formal term and framework for it.

Ansari's first theology course at Hartford Seminary, "Introduction to Islamic Theology," with Timothy Winter, a prominent academic and Muslim intellectual based at the University of Cambridge, UK, took place in fall 2007. The course "was very intellectual," Ansari remembered, and "what was awesome about it was that Winter is an expert on [the thought of Abu Hamid] alGhazali," the twelfth-century Muslim jurist-theologian whose influence in Islamic discourses parallels those of Maimonides in Judaism or of Thomas Aquinas in Christianity. Winter guided the students through al-Ghazali's famous text, The Revival of the Religious Sciences. "Then," Ansari recalled, "Winter said that the Revival could be read as a pastoral guide." To Ansari, that characterization was an eye-opener. Winter's insight became for him a guide to looking at theology "as a pastoral means to try and preserve the flock."

"Pastoral theology" became Ansari's own shibboleth, the key to his framework of engagement with other courses and, most important, to his work as a chaplain, which he continued to do throughout his years at Hartford Seminary. I asked him what courses had stood out in that respect. Ansari responded that in terms of his work as a chaplain it was the "Islamic Ethics" course taught by Ingrid Mattson, Professor of Islamic Studies and founder of the Islamic Chaplaincy Program that stood out. Ansari had taken the course near the end of the MA part of his program, while preparing to write a thesis that reflected upon "the challenge of leading my flock, Muslim women, mostly African Americans" at the Federal Correctional Institution in Danbury, CT. Mattson's course allowed him to formulate an ethical and pastoral approach to a situation that

8 See Chapter 3, "Redemption," in Timur R. Yuskaev, Speaking Qur'an: an American Scripture (Columbia, SC: University of South Carolina Press, 2017). 
had arisen, and that other male religious authorities - imams in local mosques who were called upon by the prison's administration—-perceived through the lens of jurisprudence.

The case involved a dilemma: incarcerated Muslim women demanded that prison authorities allow them to hold weekly Friday congregational prayers led by an imam. Local imams, while sympathetic to the intent behind this request, responded that, legally speaking, women are not required to attend Friday congregational prayers. They added that they were already taking care of their own flocks and could not come to the prison on Friday afternoons. To Ansari, this response was tone-deaf; it went against the grain of his sense of theologicallyinfused pastoral care. While aware of juristic intricacies, he decided to volunteer as the imam/chaplain to lead afternoon Friday prayers for the women at Danbury prison. His response was informed by Mattson's course, where he had learned that "ethics is a blend between theology and law, and that's how I was focusing on it and that's how it was helpful: it helped me to come up with an ethical response" to the dilemma. ${ }^{9}$

Winter and Mattson's courses proved to be crucial in Ansari's theological education. The course that informed Ansari's "Thug Theodicy" more directly, however, was "Suffering, Theodicy, and Repentance: Interreligious Readings of Job and Jonah," taught by Yehezkel Landau, Hartford Seminary's first Jewish core faculty member and Director of the Abrahamic Partnership Program..$^{10}$ The course resonated, Ansari explained, because he could see parallels with African American experience in Landau's discussions of Jewish theological discourses. Central was the course's "insight into Jewish scholarship, thought, critique - just how much scholarship and work they put in into their theological wrestling," especially, he highlighted, when it comes to "the challenge of theodicy." As Ansari perceived many years later when he felt the call to respond as a Muslim chaplain at the time of Black Lives Matter, theodicy was the challenge of Shakur's "So Many Tears." Beyond Landau's course at Hartford Seminary, what went into Ansari's meditation on theodicy in Shakur's masterpiece

9 See Bilal Ansari, "The Foundations of Pastoral Care in Islam: Reviving the Pastoral Voice in Islamic Prison Chaplaincy" (MA diss., Hartford Seminary, 2011); Harvey Stark, "Looking for Leadership: Discovering American Islam in the Muslim Chaplaincy" (PhD diss., Princeton University, 2015); and Timur Yuskaev and Harvey Stark, "Imams and Chaplains as American Religious Professionals," in Jane I. Smith and Yvonne Yazbeck Haddad, eds., The Oxford Handbook of American Islam (Oxford: Oxford University Press, 2015), 47-63.

10 Yehezkel Landau, "Building Abrahamic Partnerships: A Model Interfaith Program at Hartford Seminary," in David A. Roozen and Heidi Hadsell, eds., Changing the Way Seminaries Teach: Pedagogies for Interfaith Dialogue (Hartford, MA: Hartford Seminary, 2009), $84^{-120 .}$ 
was his study of the thought of Howard Thurman and Judith Butler at the Pacific School of Religion, under the guidance of Dorsey Blake, Ansari's DMin advisor there, and Munir Jiwa, Associate Professor of Islamic Studies and Anthropology at the Graduate Theological Union's Center for Islamic Studies. In between, permeating all of this, was his mostly informal study of Edward Said through conversations with his wife, Colleen Keyes, also a Hartford Seminary graduate.

From Said, Ansari borrowed the insight into the paradoxical power of public intellectuals' out-of-placeness. As a chaplain, he has been cultivating the ability to speak from an "exilic" place, of not being confined to routine, and to everyday senses of place, justice, and politics. One can sense the religious, interreligious, and pastoral dimensions in Ansari's "Thug Life Theodicy." The piece brings readers into a conversation with Abrahamic scriptures and Shakur's sorrowful psalm, and, through this shared ground, it responds to their "pain" and "apathy" and offers hope. Once Ansari's pastoral theology framework is apparent, traces of what he learned in places like Hartford Seminary become somewhat salient. Yet where is the theology in his cyber sermon?

My sense is that it is in Ansari's timing, in his theological "wrestling" with his and his readers' sense of time. Consider, for example, how he utilizes the very medium of his online reflection. His text-especially its meditative break, an excerpt from Shakur's supplication-is judiciously interleaved with links to other texts, from Isaiah 54:17 to "Signs \& Symptoms of Suicidal Ideation."11 These cyber pathways serve to disorder readers' routine sense of time. Visiting those additional, ever-multiplying cyberspaces while listening to Shakur's song becomes impossible to resist: it takes more than the allotted seven minutes to really read Ansari's multilayered text. This accomplishes an effect of a particular type of latency: an ever-present possibility of expansion and deepening of time, from the secular " 7 min" to the time of eternity. It becomes pronounced in the cyber sermon's final note, the supplication at the end of the second unit:

I pray that we today press on, holding tight to the rope of God, in order to live righteous lives despite the difficulties of this temporal life. I pray that we today continue our longing for God's grace despite the misery of life. Dear God, our trust in You is firm and we hope that the archetypal Black

11 Bible Gateway, Isaiah 54:17 (KJV), accessed June 13, 2017, https://www.biblegateway.com/ passage/?search=Isaiah+54\%3A17\&version=KJV; and Valley Behavioral Health System, "Signs and Symptoms of Suicidal Ideation," accessed June 13, 2017, http://www.valleybehavioral.com/suicidal-ideation/signs-symptoms-causes. 
man has the weight of at least a mustard seed that opens heaven's door to him and those unjustly oppressed.

Sermonizing is a genre of oral communication. A sermon's meanings depend on its sound. That is why, while preparing this chapter, I emailed Ansari with a follow-up question. I wanted to know what word he would emphasize if he had a chance to speak that supplication out loud. I shared with him a hunch: based on the fact that he timed his piece to be released exactly on September 13-to the day twenty years after Shakur's "So Many Tears" and nineteen years after his death - and guessed that Ansari would stress the word "today" in the first sentence of his supplication. Tied to this would be other time-bending emphases: "life," “temporal lives," “God's grace," and “mustard seed." “Am I correct?" I asked. Ansari confirmed it: "You are correct with your interpretation and my intention with the word choice of 'today," he said, adding, "I meant it like al-Asr."12

Ansari's deeply theological response is made even more profound by the fact that his "Thug Life Theodicy" does not directly reference the Qur'anic chapter al-Asr. It is certainly there but as a deep allusion, even more deeply embedded in the text than his cyber links. Undergirding Ansari's sermon is his theological sensibility of time informed by the revelation. The word 'asr in Qur'an 103 is polyvocal: it is a play on the word "day/afternoon" that also means "time" and "Time," as in a moment, which can be any moment, of ingathering, crystallization of time (pasts, presents, and futures that have or will have passed). Ansari's fluent, instinctual, deeply-ingrained ability to speak from the Qur'anic sense of time is central to his pastoral work. He explained that his use of the phrase "archetypal Black Man" was in "the James Weldon Johnson mode." ${ }^{13}$ Yet this "archetypal" sense is also, at the very same time, Qur'anic, attuned to the way the word insan ("human") comes across in Qur'an 103, as at once singular and plural, directed at all humanity and at each individual. It is in this sense, connected to Ansari's specific flock, that his pastoral theology comes alive. And this is where Ansari's answer to Shakur and his peers' question, "Is there heaven for a G?" comes from. Ansari's answer, as he spelled out in our interview, is that "our theology allows room for people like Tupac; I think there is room in my theology, in my pastoral theology [his emphasis], for those who have been dismissed. I believe that heaven is spacious."

12 Bilal Ansari, email interview with author, March 22, 2017.

13 See James Weldon Johnson, God's Trombones: Seven Negro Sermons in Verse (New York: The Viking Press, 1927). 
"What is your relationship with Him?" asked the de-facto Muslim chaplain to three incarcerated teenagers, hoping for a reply from the person at the center of that day's controversy, the girl who had refused to take off her scarf. The chaplain knew that their class was only forty-five minutes, and that it might be the only time she would be able to share with them. Through conversation she guided them to a point where they could tell their stories, ask their questions. Eventually, the girl asked, "Can I remove the scarf?" "How did you respond," I inquired. "She was asking me a fighi (legal/jurisprudential) question," the chaplain explained, but "I approached it from a theological perspective." That approach led her to continue the conversation.

The girl in hijab eventually shared that it was her "Muslim boyfriend" who had led her to believe that the repercussion for removing the scarf was "going to hell." She later confided, "You know, I don't understand, how can I shower?" The chaplain recalled telling the young woman, "You are going to run into a lot of people who are going to tell you a lot of things: 'You're not Muslim if you do this or that.' [But] we are given a kind of a gut check: trust enough to know that you can ask for another opinion." That was a pastoral response in many ways. The general contours of the situation were fairly typical — many teenagers in the institution had been "pressured by their boyfriends" to do all kinds of things. Knowing that they had "permission to ask questions" and seek advice from other authorities could help them find the power to break through cycles of abuse. Where does that permission come from? At the end of the class, the chaplain finally gave her answer: "God's mercy is broader than this."

The teacher/chaplain shared this story with me when I asked her to talk about a particular situation in which her Hartford Seminary training came into play. As in Ansari's case, timing was crucial. At the time of her encounter with the hijabi rebel she was taking the "Chaplaincy: Models and Methods" course with Lucinda Mosher, director of the seminary's Multifaith Chaplaincy Program. "I would have approached this interaction differently if I didn't have that chaplaincy course," she recalled. "I remember thinking, I have to address this carefully, and I have to bring the other girls, and [we] can't have a one-on-one conversation, and ... how do I interact in a way that doesn't impose?" This technique of instantaneous assessment, she explained, came from Mosher's chaplaincy course.

The next crucial step-the chaplain's decision not to rush into a boilerplate response to a seemingly legalistic question - was informed by another theology course, also taught by Mosher, "Christian-Muslim Encounter: The Theological Dimension." Before she told me about it, however, we spoke about her Muslim theological education before and during her years at Hartford Seminary. Like Ansari and many other students, she had enrolled in the seminary 
after having done some serious, albeit often informal, study. While growing up she had attended an Islamic elementary school, but the most important factor was that her parents, who took religious study and exploration very seriously, had home-schooled her all the way through high school. After college, a period in which it seemed to her that there was "a gap in deep thinking about God," she worked "in a nonprofit, as a case manager and then manager of case managers, working with low-income families." Concurrently she spent her "evenings hopping to khalaqas, Qur'an study circles." She went to Harford Seminary in part because she had found herself "really seeking more of an academic understanding of religion." The Islamic theology courses she attended at the seminary were useful, she recalled: "They gave me an understanding of the history of Muslim theological thought." Yet, somehow, the comparative theology course with Mosher made the difference in that specific chaplaincy situation.

To find out a bit more about this, I reached out to Mosher, who explained in an email interview that she based her approach on a theological wrestling of sorts, an engagement with theologies of other human beings that stresses "the relation between theology and empathy in action."14 My hunch is that it was this aspect of the course that proved crucial in the chaplain's disciplined determination to continue the conversation, and in her ability to infuse it, at the right time, with the deeply theological notion of "God's mercy is broader than this."

What was the role of Hartford Seminary's theological education in the two chaplains' stories? The seminary coursework that made the most tangible impact in both cases, in moments when it really mattered, was intersectional. For Ansari, the Islamic theology course he remembered infused pastoral care into theology. Added to the mix was a course that "blended theology and law" and one in comparative "theological wrestling." His colleague's path was comparable. Unlike Ansari, she did not find her Islamic theology course immediately productive; it had been informative but not formational. Like him, however, the courses she considered most impactful interweaved comparative theological engagement with pastoral care. Of course, in both cases, such interweaving was dialogical. The combination of the three threads - theological, comparative, and pastoral — resonated with both my interviewees because of their own

14 Lucinda Mosher, email interview with author, March 20, 2017. Mosher's comparative theology course echoes Francis x. Clooney's Comparative Theology: Deep Learning Across Religious Borders (Malden, MA and Oxford: Wiley-Blackwell, 2010). 
professional and personal callings. As chaplains in training they gravitated toward courses that stressed the "relation between theology and empathy in action." And, as an institution that trains chaplains, it was natural for Hartford Seminary to offer such courses. Also not coincidental is the fact that two of the faculty members mentioned here, Ingrid Mattson and Lucinda Mosher, were directly involved in shaping the seminary's chaplaincy education. Yet the lessons of these stories, the dynamics within them, are broader than the Hartford Seminary and other theological schools' chaplaincy programs, and because of this, the importance of what we do is also broad.

To explain what I mean by this, it is useful to begin with chaplaincy. Ansari and his anonymous colleague had done chaplaincy-type work prior to their seminary studies. This had shaped their priorities, the agendas that informed what they sought in the courses they took. What they needed were frameworks, terminologies, skills. What they found were courses that honed their personal and latent professional sensibilities and allowed them to respond to tough challenges instinctually, within a blink of time. Similarly, what they thought about God, their "relationship with Him," had been shaped in their pre-seminary lives and study. They had applied to the seminary seeking a more formal theological education. They found theology courses in their own tradition to be essential. Such courses provided them with deeper vocabulary, frameworks, logistics, and familiarity with historical and current precedentsall of which enabled them to function as religious professionals. Yet, as important as the academic aspect was to both chaplains, the "pastoral" fine-tuning is what made all the difference.

As I was mulling over this chapter, I related the story of the chaplain in the juvenile detention facility to one of my colleagues, Benjamin Watts, director of the Black Ministries program at Hartford Seminary. I asked him, "Where is our theological education in that story?" "Well," he said, "it is about moments when we need to live our theology in tight spaces." For chaplains, the need for this is obvious. The stories I have related in this chapter are about two chaplains' ability, refined in part through their study at Hartford Seminary, to infuse deep theology into "tight spaces" - through a word ("today"), or a brief phrase ("God's mercy is broader than this"), or perhaps even through the seemingly minor act of continuing a conversation. This last detail, the learned discipline of continuing conversations, signals an additional side to these stories: comparative theology courses were crucial to both chaplains. The tight spaces they inhabit professionally are tight in the sense of being tough, but they are also tight in the sense of just how densely pluralistic they are. In that sense, they are more condensed versions of the spaces inhabited by most of our students and graduates, not only chaplains. 
It is useful to remember here that, like the audiences they addressed in the above episodes, Ansari and his anonymous colleague are complex human beings whose lives and actions "absorb and refract" myriads of histories and, crucially, historical and current hierarchies of power, in which they find themselves as "problematic minorities," human beings marked not just by a degree of marginality but also by a state of liminality - a condition in which individuals associated with a "problematic" minority group find themselves at the center of disciplines and discourses that enforce what is (and is not) "normative."15

In the United States, the location I share with my interlocutors, institutional practices of belonging within hierarchies of power have consistently revolved around such liminal groups: African Americans, Native Americans, Catholics, Jews, Arab Americans, Asian Americans, Muslims, and many others, including groups classified and disciplined through concepts of "normative" genders. Particular clusters of such groups have come into the center of attention at specific points in history, always connected with numerous local and global developments, such as the "War on Terror" or the Vietnam War. ${ }^{16}$ Therefore, this chapter's (of necessity limited) focus on Muslims, a problematic minority, and a preeminent current post-9/11, highlights deeper and broader, and unavoidably—at least latently—problematic dynamics that absorb and refract the experiences of many other minorities.

This matters for interreligious theological schools because the diversity of students we attempt to cultivate is not flat; it not a mere collection of diverse profiles/imagined identities, but rather represents human beings whose lives are enmeshed in hierarchies of power, including, crucially, systems of racialized class prejudice. Interweaved in this human, embodied history and ongoing, never-ending politics, there are also theologies, or rather theological sensibilities. (Remember the chaplain's question, "What is your relationship with Him?" The emphasis on relationship speaks to sensibilities, not formal theologies.) The pluralistic spaces our students inhabit are multidirectional, in the sense of embodied histories and politics. At the same time, done right, interreligious theological education hones in our students a sense of such pluralistic spaces being multidimensional as well. This multidimensional aspect of pluralistic spaces is difficult to express in words; it is best sensed-and a

\footnotetext{
15 See, for example, George Yancy, ed., Christology and Whiteness: What Would Jesus Do? (New York: Routledge, 2012).

16 See, for example, Moustafa Bayoumi, How Does It Feel to Be a Problem? Being Young and Arab in America (New York: Penguin Press, 2009); and Cathy Schlund-Vials, Modeling Citizenship:Jewish and Asian American Writing (Philadelphia: Temple University Press, 2011). My "absorb and refract" wording at the top of this paragraph is a refraction of a phrase by Moustafa Bayoumi; see Bayoumi, How Does It Feel to Be a Problem? 121.
} 
theologically informed work of "empathy in action" is a way to cultivate it. At the end of the day, a place like Hartford Seminary, a graduate school of interreligious theological education, is not just about imparting academic knowledge, but also honing our students' theological sensibilities, including, crucially, their ability to foster and use in transformative, deeply political ways the sense of belonging to multidimensional time (as in Ansari's "today/ 'asr").

Why does interreligious theological education matter? It matters because of the way it infuses theological sensibilities into tight spaces; because of the way it can make our pluralism, our commitment to, and our work within pluralism, deeper. It matters because without the discipline of honing our theological sensibilities, a "7 min" engagement with a text or a human being may go no deeper than a flat, linear seven minutes - and pluralism might just be a collage or a wrestling arena of shallow/shadow identities. To make pluralism really work we need a sense of "God's mercy is broader than this." To make it sustainable as a social reality, we need educational institutions that hone and inform such sensibilities, and enable their graduates, whatever professional paths they end up pursuing, to express and embody it one crucial, transformative moment at a time.

\section{Bibliography}

Ansari, Bilal. "The Foundations of Pastoral Care in Islam: Reviving the Pastoral Voice in Islamic Prison Chaplaincy." MA diss. Hartford Seminary, 2011.

Ansari, Bilal. "Thug Life Theodicy - A Mustard Seed of Faith: Reflections on the 2oth Anniversary of Tupac Shakur's Song 'So Many Tears." Accessed June 23, 2017. https://ummahwide.com/thug-life-theodicy-a-mustard-seed-of-faith-5bb62c88 dfc2\#.15vj9wcv9.

Bakhtin, Mikhail. Toward a Methodology for the Human Sciences: Speech Genres \& Other Late Essays, translated by Vern W. McGee. Austin, TX: University of Texas Press, 1986.

Bayoumi, Moustafa. How Does It Feel to Be a Problem:Being Young and Arab in America. New York: Penguin Press, 2009.

Clooney, Francis X. Comparative Theology: Deep Learning Across Religious Borders. Malden, MA and Oxford: Wiley-Blackwell, 2010.

Connolly, William E. Pluralism. Durham, NC: Duke University Press, 2005.

Landau, Yehezkel. "Building Abrahamic Partnerships: A Model Interfaith Program at Hartford Seminary." In David A. Roozen and Heidi Hadsell, eds., Changing the Way Seminaries Teach: Pedagogies for Interfaith Dialogue, 85-120. Hartford, MA: Hartford Seminary, 2009 . 
Schlund-Vials, Cathy. Modeling Citizenship: Jewish and Asian American Writing. Philadelphia: Temple University Press, 2011.

Stark, Harvey. "Looking for Leadership: Discovering American Islam in the Muslim Chaplaincy." Ph.D. diss., Princeton University, 2015.

Weldon Johnson, James. God's Trombones: Seven Negro Sermons in Verse. New York: The Viking Press, 1927.

Yancy, George, ed. Christology and Whiteness: What Would Jesus Do? New York: Routledge, 2012.

Yuskaev, Timur R. Speaking Qur'an: an American Scripture. Columbia, SC: University of South Carolina Press, 2017.

Yuskaev, Timur R., and Harvey Stark. "Imams and Chaplains as American Religious Professionals." In Jane I. Smith and Yvonne Yazbeck Haddad, eds., The Oxford Handbook of American Islam, 47-63. Oxford: Oxford University Press, 2015. 